\title{
PENGARUH DOSIS BOKASHI TERHADAP PERTUMBUHAN DAN PRODUKSI PADA PEMOTONGAN PERTAMA RUMPUT GAJAH MINI (Pennisetum Purpureum cv. Mott)
}

\author{
The Effect of Bokashi Dosage on Growth and Production In The First Harvest of Dwarf Elephant \\ Grass (Pennisetum Purpureum Cv. Mott)
}

Azaria Dhea Gantina, Farida Fathul, Liman, dan Muhtarudin

\author{
Department of Animal Husbandry, Faculty of Agriculture, Lampung University \\ Jl. Prof. Soemantri Brojonegoro No. 1 Gedung Meneng Bandar Lampung 35145 \\ e-mail: azariadheagantina@gmail.com
}

\begin{abstract}
This research aims was to determine the effect of bokashi dose on plant height, number of tillers, percentage of stems, fresh production, and dry matter production and also to determine the optimum dose of bokashi to obtain the best results on growth and production at the first harvest of dwarf elephant grass. This research was conducted in March 2020 - July 2020 in Sidodadi Asri village, Jati Agung district, South Lampung regency. This research used a Completely Randomized Design (CRD) with 4 levels of treatment, namely P0 (control); P1 (bokashi dosage 30 tons/ha); P2 (bokashi dosage 40 tons/ha); and P3 (bokashi dosage 50 tons/ha). Each experimental treatment unit has plot measuring $2 \times 2 \mathrm{~m}^{2}$. Each trial unit was repeated 3 times, so there were 12 trial units. The data were analyzed by variations analyzed at $5 \%$ and or $1 \%$ level, after that it was followed by orthogonal polynomial test. The results showed that the dose of bokashi had a significant effect $(\mathrm{P}<0,05)$ on plant height, fresh production, and dry production, but had no significant effect $(\mathrm{P}>0,05)$ on number of tillers, and percentage of stems. The effect of bokashi fertilizer on plant height was obtained by using the optimum bokashi dose of 36.73 tons/ha and the equation was $\hat{Y}=60,13+35,38 x-6.62 x^{2}[0$; 50 ton $/ \mathrm{Ha}](\mathrm{P}<0,01)$. The optimum dose was not obtained for the number of tillers, percentage of stems, fresh production, and dry production.
\end{abstract}

Keywords: Plant height, Number of tillers, Percentage of stems, Fresh production, Dry production

\begin{abstract}
ABSTRAK
Penelitian ini bertujuan untuk mengetahui pengaruh dosis bokashi terhadap tinggi tanaman, jumlah anakan, persentasi batang, produksi berat segar, dan produksi bahan kering serta untuk mengetahui dosis bokashi yang optimum untuk mendapatkan hasil yang terbaik pada pertumbuhan dan produksi pada pemotongan pertama rumput gajah mini. Penelitian ini dilaksanakan pada Maret 2020 - Juli 2020 di Sidodadi Asri, Jati Agung, Lampung Selatan. Penelitian ini menggunakan Rancangan Acak Lengkap (RAL) dengan empat taraf perlakuan, yaitu P0 (kontrol); P1 (dosis bokashi 30 ton/ha); P2 (dosis bokashi 40 ton/ha); dan P3 (dosis bokashi 50 ton/ha). Setiap unit perlakuan percobaan berupa petak berukuran $2 \times 2 \mathrm{~m}^{2}$. Setiap unit percobaan diulang sebanyak 3 kali, sehingga terdapat 12 unit percobaan. Data yang diperoleh dianalisis ragam pada taraf nyata $5 \%$ dan atau $1 \%$, setelah itu dilanjutkan dengan uji polinomial ortogonal. Hasil penelitian menunjukkan bahwa dosis bokashi berpengaruh nyata $(\mathrm{P}<0,05)$ terhadap tinggi tanaman, produksi berat segar, dan produksi bahan kering, namun tidak berpengaruh nyata $(\mathrm{P}>0,05)$ terhadap jumlah anakan dan persentasi batang. Pengaruh pupuk bokashi terhadap tinggi tanaman diperoleh penggunaan dosis bokashi optimum sebesar 36,73 ton/Ha dan menghasilkan persamaan sebagai berikut $\hat{Y}=60,13+35,38 x-6.62 x^{2}[0$ ; 50 ton/Ha] pada $(\mathrm{P}<0,01)$. Pada jumlah anakan, persentasi batang, produksi berat segar, dan produksi bahan kering tidak diperoleh dosis optimum.
\end{abstract}

Kata Kunci: Tinggi tanaman, Jumlah anakan, Persentasi batang, Produksi berat segar, Produksi bahan kering 


\section{PENDAHULUAN}

Upaya untuk meningkatkan produksi peternakan secara cepat hanya dapat dicapai apabila ditunjang dengan penyediaan pakan yang berkualitas. Pada saat ini untuk menanggulangi masalah kekurangan pakan hijauan telah diperkenalkan dan dikembangkan bermacammacam jenis hijauan, salah satu sumber utama pakan hijauan adalah berasal dari rumput. Rumput yang sangat potensial dan sering diberikan pada ternak ruminansia salah satunya adalah rumput gajah mini (Pennisetum Purpureum cv. Mott). Rumput gajah mini merupakan jenis rumput hijauan pakan yang potensial untuk dikembangkan di Indonesia. Menurut Lasamadi (2013) rumput gajah mini merupakan tanaman yang produktif dan dapat menghasilkan anakan yang cukup banyak, mempunyai akar kuat, batang yang tidak keras dan mempunyai ruas daun yang banyak serta struktur daun yang muda sehingga sangat disukai oleh ternak.

Upaya peningkatan produksi hijauan dapat dicapai dengan melakukan pemeliharaan yang baik, salah satunya adalah pemupukan tanaman. Pemupukan rumput gajah mini menggunakan pupuk bokashi merupakan suatu bentuk integrasi antara ternak dengan hijauan, dimana kotoran sapi dimanfaatkan untuk meningkatkan pertumbuhan dan produksi hijauan.

Tola dan Dahlan (2007) menyatakan bahwa Pupuk bokashi kotoran sapi merupakan salah satu alternatif dalam penerapan teknologi pertanian organik yang berwawasan lingkungan dan berkelanjutan. Arinong (2005) menyatakan bahwa bahan organik berperan penting dalam meningkatkan kesuburan tanah melalui perbaikan sifat fisik, kimia, dan biologis tanah. Menurut Noor dan Ningsih (2001), bokashi kotoran sapi merupakan pupuk lengkap, yang mengandung unsur hara makro dan mikro. Kandungan unsur hara bokashi kotoran sapi adalah Nitrogen $(\mathrm{N})$ sebesar $0,92 \%$, Posfor (P) 0,23\%, Kalium (K) 1,03\%, serta mengandung $\mathrm{Ca}, \mathrm{Mg}$, dan sejumlah unsur mikro lainnya seperti $\mathrm{Fe}, \mathrm{Cu}, \mathrm{Mn}, \mathrm{Zn}$, Bo, dan Mo, yang berfungsi sebagai bahan makanan bagi pertumbuhan dan perkembangan tanaman.

Berdasarkan uraian di atas maka perlu dilakukan penelitian untuk mengetahui pengaruh dosis penambahan bokashi terhadap pertumbuhan dan produksi yang meliputi tinggi tanaman, jumlah anakan, proporsi daun, produksi berat segar, dan produksi bahan kering, pada pemotongan pertama rumput gajah mini (Pennisetum Purpureum cv. Mott).

\section{MATERI DAN METODE}

Penelitian ini dilaksanakan pada Maret 2020 - Juli 2020 di Sidodadi Asri, Jati Agung, Lampung Selatan untuk budidaya hijauan dan analisis kandungan bahan kering dilakukan di Laboratorium Nutrisi dan Makanan Ternak, Jurusan Peternakan, Fakultas Pertanian, Universitas Lampung.

\section{Materi}

Alat-alat yang digunakan yaitu cangkul, sabit, timbangan gantung, timbangan analitik, meteran, waring, karung goni, terpal, trashbag hitam, ember, tali rafia, dan alat tulis.

Bahan-bahan yang digunakan yaitu bibit rumput gajah mini (Pennisetum Purpureum cv. $M o t t$ ), pupuk bokashi, air sumur, dan lahan seluas $100 \mathrm{~m}^{2}$.

\section{Metode}

\section{Rancangan Perlakuan}

Penelitian ini menggunakan Rancangan Acak Lengkap (RAL) dengan empat taraf perlakuan, yaitu P0 (kontrol); P1 (dosis bokashi 30 ton/ha); P2 (dosis bokashi 40 ton/ha); dan P3 (dosis bokashi 50 ton/ha). Setiap unit perlakuan percobaan berupa petak berukuran $2 \times 2 \mathrm{~m}^{2}$. Setiap unit percobaan diulang sebanyak 3 kali, sehingga terdapat 12 unit percobaan.

\section{Pelaksanaan Penelitian}

Penelitian ini terdiri dari beberapa tahapan, yang pertama tahap pembuatan bokashi dengan komposisi pupuk kandang kotoran sapi $100 \mathrm{~kg}$, dedak $2 \mathrm{~kg}$, sekam $12 \mathrm{~kg}$, EM4 $40 \mathrm{ml}$, molases 2 sdm, dan air secukupnya yang kemudian difermentasi selama 14 hari.

Lahan diberi pupuk bokashi dua kali yaitu tiga hari sebelum penanaman dan setelah dilakukannya potong paksa pada umur 50 hari dengan dosis $3 \mathrm{~kg} /$ petak (30 ton $/ \mathrm{ha}$ ), $4 \mathrm{~kg} /$ petak (40 ton/ha), $5 \mathrm{~kg} /$ petak (50 ton/ha), serta kontrol (tanpa pupuk). Bibit rumput berupa stek dengan lima ruas, penanaman rumput dengan cara memasukkan 3/4 bagian dari panjang stek.

Setelah rumput berumur 50 hari dilakukan pemotongan paksa untuk menyeragamkan umur tanaman. Hijauan kemudian dipanen 40 hari setelah potong paksa. Hijauan hasil panen dalam bentuk segar kemudian dikeringkan dan dihaluskan untuk dilakukan analisis kandungan bahan kering. 


\section{Peubah yang Diukur}

Peubah yang diukur dalam penelitian ini yaitu tinggi tanaman, jumlah anakan, persentasi batang, produksi berat segar, dan produksi bahan kering.

\section{Analisis Data}

Data yang diperoleh dianalisis dengan analisis variansi (ANOVA) dan dilanjut dengan uji polinomial ortogonal

\section{HASIL DAN PEMBAHASAN}

Pengaruh Dosis Bokashi terhadap Tinggi Tanaman pada Pemotongan Pertama Rumput Gajah Mini (Pennisetum Purpureum cv. Mott)

Data hasil pengaruh dosis bokashi terhadap tinggi tanaman pada pemotongan pertama rumput gajah mini disajikan dalam Tabel 1.

Tabel 1. Pengaruh perlakuan terhadap tinggi tanaman rumput gajah mini

\begin{tabular}{|c|c|c|c|c|}
\hline \multirow{3}{*}{$\begin{array}{c}\text { Perlakua } \\
\text { n }\end{array}$} & \multicolumn{3}{|c|}{ Ulangan } & \multirow{2}{*}{ Rata-rata } \\
\hline & 1 & 2 & 3 & \\
\hline & \multicolumn{4}{|c|}{--------------------cm--------------------------------- } \\
\hline P0 & $\begin{array}{c}88,3 \\
3\end{array}$ & $\begin{array}{c}94,3 \\
3\end{array}$ & $\begin{array}{c}84,0 \\
0\end{array}$ & $88.89 \pm 5,19$ \\
\hline P1 & $\begin{array}{c}94,0 \\
0\end{array}$ & $\begin{array}{c}89,5 \\
0\end{array}$ & $\begin{array}{c}92,8 \\
3\end{array}$ & $92.11 \pm 2,33$ \\
\hline P2 & $\begin{array}{c}112,6 \\
7\end{array}$ & $\begin{array}{c}102,8 \\
3\end{array}$ & $\begin{array}{c}104,6 \\
0\end{array}$ & $106.70 \pm 5,25$ \\
\hline $\mathrm{P} 3$ & $\begin{array}{c}86,3 \\
3 \\
\end{array}$ & $\begin{array}{c}94,6 \\
0 \\
\end{array}$ & $\begin{array}{c}106,3 \\
3 \\
\end{array}$ & $\begin{array}{c}95.75 \pm 10,0 \\
5 \\
\end{array}$ \\
\hline
\end{tabular}

Keterangan : P0 = kontrol (tanpa bokashi) $\mathrm{P} 1=$ dipupuk dengan dosis 30 ton $/ \mathrm{Ha}=$

3000 gram bokashi / petak percobaan

$\mathrm{P} 2$ = dipupuk dengan dosis 40 ton $/ \mathrm{Ha}=$

4000 gram bokashi / petak percobaan

$\mathrm{P} 3=$ dipupuk dengan dosis 50 ton $/ \mathrm{Ha}=$

5000 gram bokashi / petak percobaan

Berdasarkan hasil analisis ragam menunjukkan bahwa perlakuan dosis bokashi berpengaruh nyata $(\mathrm{P}<0,05)$ terhadap rata-rata tinggi tanaman rumput gajah mini yakni perbedaan dosis bokashi di setiap petaknya yang mengakibatkan dosis $\mathrm{C} / \mathrm{N}$ semakin banyak. Hasil rata-rata tinggi tanaman rumput gajah mini pada perlakuan P0 menempati posisi terendah yaitu dengan rata rata $88.89 \pm 5.19 \mathrm{~cm}$, sedangkan yang tertinggi pada perlakuan P2 yaitu dengan rata rata $106.70 \pm 5.25 \mathrm{~cm}$.
Berdasarkan hasil uji lanjut polinomial ortogonal disajikan pada Gambar 1. diperoleh persamaan $\hat{Y}=60,13+35,38 x-6.62 x^{2}[0 ; 50$ ton/Ha] ( $\hat{Y}$ sebagai variabel terikat dan $\mathrm{x}$ sebagai variabel bebas) pada $(\mathrm{P}<0,01)$.

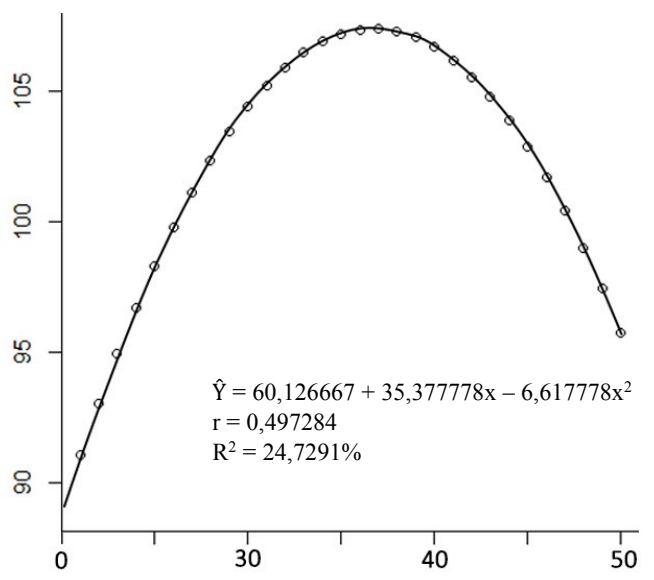

Gambar 1. Grafik tinggi tanaman

Berdasarkan persamaan tersebut maka diperoleh titik optimum dosis bokashi terhadap tinggi tanaman sebesar 36,73ton/Ha dan mengalami penurunan setelah melewati titik optimum, sehingga membentuk persamaan parabola. Nilai $r$ (koefisien korelasi) diperoleh sebesar 0,50 yang berarti hubungannya sedang. Menurut Sugiyono (2013), jika interval koefisien sebesar 0,40 - 0,599 maka tingkat hubungan dikatakan sedang. Berdasarkan hasil nilai $r$ tingkat hubungannya sedang dan positif antara dosis bokashi terhadap tinggi tanaman. Nilai $\mathrm{R}^{2}$ (koefisien determinasi) diperoleh sebesar 24,73\% menunjukkan bahwa bokashi berpengaruh terhadap tinggi tanaman sebesar $24,73 \%$, sedangkan sisanya $(100 \%-24,73 \%=75,27 \%)$ dipengaruhi oleh variabel lain. Artinya pengaruh terhadap tinggi tanaman kecil. Pada penelitian ini persamaan terhadap tinggi tanaman dengan adanya pupuk bokashi $\hat{Y}=60,13+35,38 x-6.62 x^{2}[0 ; 50$ ton $/ \mathrm{Ha}]$ dapat digunakan untuk memprediksi tinggi tanaman rumput gajah mini pada dosis $0-50$ ton/Ha.

Pemberian dosis bokashi sebesar 36,73 ton/Ha menghasilkan tinggi tanaman tertinggi pada rumput gajah mini dan jika pemberian dosis bokashi melebihi titik optimum maka tinggi tanaman rumput gajah mini mengalami penurunan. Peningkatan tinggi tanaman berkaitan dengan proses adaptasi 
tanaman terhadap kondisi lingkungan seperti cahaya, ketersediaan air dan unsur hara. Hasil penelitian Sadjadi et al. (2017) menunjukan bahwa perlakuan level bokashi kotoran sapi berpengaruh sangat nyata $(\mathrm{P}<0,01)$ terhadap pertumbuhan tinggi tanaman rumput raja. Berdasarkan penelitian tersebut, diketahui bahwa semakin tinggi level bokasi kotoran sapi yang diberikan, semakin tinggi pula laju pertumbuhan tinggi tanaman.

Tinggi tanaman berkolerasi terhadap penambahan unsur hara pada tanah yang berasal dari pemupukan. Bokashi dapat meningkatkan dan memperbaiki kandungan unsur hara tanah karena bokashi kotoran sapi mengandung bahan organik yang dapat meningkatkan kesuburan tanah. Bokashi pada penelitian ini mengandung unsur hara $\mathrm{C}$ sebesar $6,41 \%$ dan $\mathrm{N}$ sebesar $1,35 \%$ atau nilai $\mathrm{C} / \mathrm{N}$ rasio sebesar 4,748. Menurut Permentan Nomor 70 (2011), standar mutu pupuk organik pada parameter $\mathrm{C} / \mathrm{N}$ rasio sebesar $15-25$. Berdasarkan hal tersebut, pupuk bokashi yang digunakan dalam penelitian ini memiliki $\mathrm{C} / \mathrm{N}$ rasio yang rendah dari standar mutu.

\section{Pengaruh Dosis Bokashi terhadap Jumlah Anakan pada Pemotongan Pertama Rumput Gajah Mini (Pennisetum Purpureum cv. Mott)}

Data hasil pengaruh dosis bokashi terhadap jumlah anakan pada pemotongan pertama rumput gajah mini disajikan dalam Tabel 2.

Tabel 2. Pengaruh perlakuan terhadap jumlah anakan rumput gajah mini

\begin{tabular}{ccccc}
\hline \multirow{3}{*}{ Perlakuan } & \multicolumn{3}{c}{ Ulangan } & \multirow{2}{*}{ Rata-rata } \\
\cline { 2 - 4 } & 1 & 2 & 3 & \\
\cline { 2 - 4 } & ----------------------------------- \\
\hline P0 & 16,00 & 21,00 & 27,00 & $21,33 \pm 5,51$ \\
P1 & 24,00 & 22,00 & 26,00 & $24,00 \pm 2,00$ \\
P2 & 24,00 & 26,00 & 28,00 & $26,00 \pm 2,00$ \\
P3 & 15,00 & 19,00 & 40,00 & $24,67 \pm 14,43$ \\
\hline
\end{tabular}

Keterangan : $\mathrm{P} 0=$ kontrol (tanpa bokashi)

$\mathrm{P} 1=$ dipupuk dengan dosis 30 ton $/ \mathrm{Ha}=$

3000 gram bokashi / petak percobaan

$\mathrm{P} 2=$ dipupuk dengan dosis 40 ton $/ \mathrm{Ha}=$

4000 gram bokashi / petak percobaan

$\mathrm{P} 3=$ dipupuk dengan dosis 50 ton $/ \mathrm{Ha}=$

5000 gram bokashi / petak percobaan

Berdasarkan

hasil analisis ragammenunjukkan bahwa perlakuan dosis bokashi tidak berpengaruh nyata $(\mathrm{P}>0,05)$ terhadap jumlah anakan rumput gajah mini. Dosis bokashi pada produktivitas rumput gajah mini khususnya pada jumlah anakan tidak berpengaruh. Rata-rata jumlah anakan pada setiap perlakuan yakni kontrol (P0) $21,33 \pm 5,51$ anakan, dosis bokashi 30 ton/ha (P1) $24,00 \pm 2,00$ anakan, dosis bokashi 40 ton/ha (P2) $26,00 \pm 2,00$ anakan, dan dosis bokashi 50 ton/ha (P3) $24,67 \pm 14,43$ anakan.

Berdasarkan hasil uji lanjut polinomial ortogonal disajikan pada Gambar 2. diperoleh persamaan $\hat{\mathrm{Y}}=15,33+7,22 \mathrm{x}-1,22 \mathrm{x}^{2}[0 ; 50$ ton/Ha] ( $\hat{Y}$ sebagai variabel terikat dan $\mathrm{x}$ sebagai variabel bebas) pada $(\mathrm{P}>0,05)$.

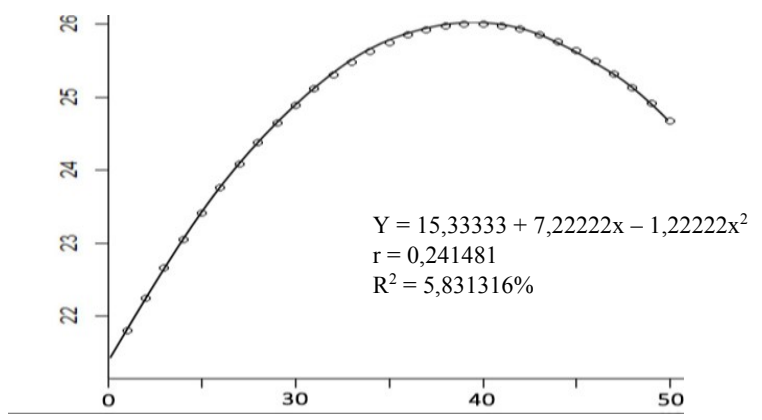

Gambar 2. Grafik jumlah anakan

Berdasarkan persamaan tersebut maka tidak diperoleh titik optimum dosis bokashi karena $\mathrm{P}>0,05$ yang artinya persamaan tersebut tidak valid. Nilai $r$ (koefisien korelasi) diperoleh sebesar 0,24 yang berarti hubungannya tidak kuat. Menurut Sugiyono (2013), jika interval koefisien sebesar 0,20 - 0,399 maka tingkat hubungan dikatakan lemah. Berdasarkan hasil nilai $r$ tingkat hubungannya yang lemah dan positif antara dosis bokashi terhadap jumlah anakan. Nilai $\mathrm{R}^{2}$ (koefisien determinasi) diperoleh sebesar 5,83\% menunjukkan bahwa bokashi berpengaruh terhadap jumlah anakan sebesar $5,83 \%$, sedangkan sisanya $(100 \%-5,83 \%=$ $94,17 \%$ ) dipengaruhi oleh variabel lain. Artinya pengaruh terhadap jumlah anakan kecil sekali.

Pemberian dosis bokashi terbaik sebesar 40 ton/Ha pada jumlah anakan rumput gajah mini. Hal ini tidak sejalan dengan hasil penelitian Sadjadi et.al. (2017) yang menunjukan bahwa perlakuan P5 (30 ton/ha) menghasilkan jumlah anakan pada rumput raja terbanyak. Hal ini disebabkan karena pada pupuk bokashi yang digunakan unsur $\mathrm{N}$ yang terkandung sebesar $1,35 \%$. Menurut Permentan Nomor 70 (2011), standar mutu pupuk organik pada parameter hara makro $\left(\mathrm{N}+\mathrm{P}_{2} \mathrm{O}_{5}+\mathrm{K}_{2} \mathrm{O}\right)$ minimal sebesar $4 \%$. Berdasarkan hal tersebut, unsur $\mathrm{N}$ yang dibutuhkan oleh tanaman kurang dari standar mutu sehingga pertumbuhan tidak maksimal.

Nitrogen $(\mathrm{N})$ berfungsi sebagai penyusun asam-asam amino, protein komponen pigmen 
klorofil yang penting dalam proses fotosintesis. Sebaliknya jika kekurangan $\mathrm{N}$ menyebabkan pertumbuhan dan perkembangan tanaman terganggu yang disebabkan oleh terganggunya pembentukan klorofil yang sangat penting untuk proses fotosintesa (Sholeh et.al.,1997). Lasamadi (2013) yang menyatakan bahwa unsur nitrogen yang terkandung dalam pupuk organik sangat besar kegunaannya bagi tanaman untuk pertumbuhan dan perkembangan, antara lain membuat daun tanaman lebih hijau segar dan banyak mengandung klorofil yang mempunyai peranan sangat penting dalam proses fotosintesis, mempercepat pertumbuhan tanaman (tinggi, jumlah anakan, cabang, dan lain - lain) serta menambah kandungan protein tanaman.

Pengaruh Dosis Bokashi terhadap Persentasi Batang pada Pemotongan Pertama Rumput Gajah Mini (Pennisetum Purpureum cv. Mott)

Data hasil pengaruh dosis bokashi terhadap persentasi batang pada pemotongan pertama rumput gajah mini disajikan dalam Tabel 3.

Tabel 3. Pengaruh perlakuan terhadap persentasi batang rumput gajah mini

\begin{tabular}{|c|c|c|c|c|}
\hline \multirow{3}{*}{ Perlakuan } & \multicolumn{3}{|c|}{ Ulangan } & \multirow[t]{2}{*}{ Rata-rata } \\
\hline & 1 & 2 & 3 & \\
\hline & \multicolumn{4}{|c|}{--------------------- \% - ----------------------- } \\
\hline P0 & 28,00 & 20,79 & 22,00 & $23,60 \pm 3,86$ \\
\hline $\mathrm{P} 1$ & 30,39 & 21,78 & 31,37 & $27,85 \pm 5,28$ \\
\hline $\mathrm{P} 2$ & 33,33 & 27,88 & 33,65 & $31,62 \pm 3,24$ \\
\hline P3 & 23,30 & 32,35 & 28,00 & $27,88 \pm 4,53$ \\
\hline
\end{tabular}

Keterangan : $\mathrm{P} 0=$ kontrol (tanpa bokashi)

$\mathrm{P} 1$ = dipupuk dengan dosis 30 ton/Ha

$=3000$ gram bokashi / petak percobaan

$\mathrm{P} 2$ = dipupuk dengan dosis 40 ton/Ha

$=4000$ gram bokashi / petak percobaan

$\mathrm{P} 3$ = dipupuk dengan dosis 50 ton/Ha

$=5000$ gram bokashi $/$ petak percobaan

Berdasarkan hasil analisis ragam menunjukkan bahwa pengaruh dosis bokashi tidak berpengaruh nyata $(\mathrm{P}>0,05)$ terhadap persentasi batang pada rumput gajah mini. Persentasi batang tertinggi terdapat pada perlakuan P3 (dosis bokashi 40 ton/Ha) yaitu $31,62 \pm 3,24 \%$. Rumput gajah mini pada perlakuan P3 memiliki batang yang sangat banyak dan daun yang sangat sedikit, sehingga menyebabkan persentasi batang jauh lebih tinggi dibanding daunnya. Sebaliknya persentasi daun menjadi meningkat. Hal ini diduga karena kurangnya penambahan unsur hara dalam tanah yang dapat meningkatkan kesuburan dan produksi tanaman, sehingga rumput gajah mini pada perlakuan kontrol tumbuh tidak sempurna yang mengakibatkan produksinya sedikit dan dapat mempengaruhi proporsi daun dan batang pada rumput gajah mini.

Berdasarkan hasil uji lanjut polinomial ortogonal disajikan pada Gambar 3. diperoleh persamaan $\hat{\mathrm{Y}}=11,84+14,34 \mathrm{x}-2,58 \mathrm{x}^{2}[0 ; 50$ ton/Ha] ( $\hat{Y}$ sebagai variabel terikat dan $\mathrm{x}$ sebagai variabel bebas) pada $(\mathrm{P}>0,05)$.

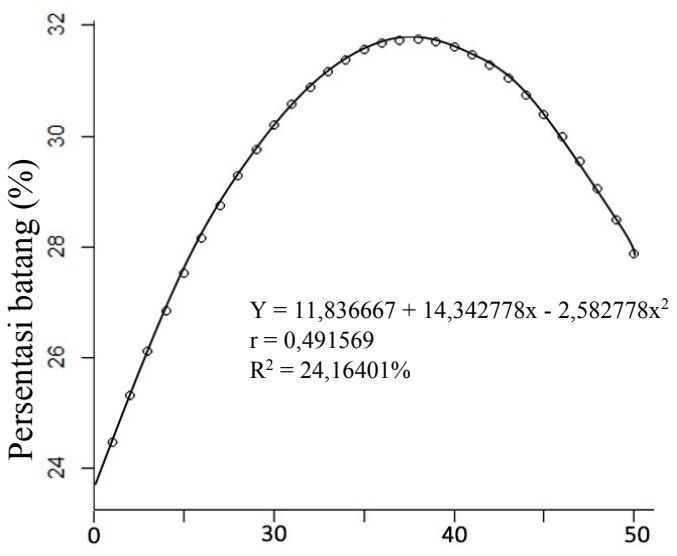

Gambar 3. Grafik persentasi batang

Berdasarkan persamaan tersebut maka tidak diperoleh titik optimum dosis bokashi karena $\mathrm{P}>0,05$ yang artinya persamaan tersebut tidak valid. Nilai r (koefisien korelasi) diperoleh sebesar 0,49 yang berarti hubungannya sedang. Menurut Sugiyono (2013), jika interval koefisien sebesar 0,40 - 0,599 maka tingkat hubungan dikatakan sedang. Berdasarkan hasil nilai $r$ tingkat hubungannya sedang dan positif antara dosis bokashi terhadap persentasi batang. Nilai $\mathrm{R}^{2}$ (koefisien determinasi) diperoleh sebesar 24,16\%menunjukkan bahwa bokashi berpengaruh terhadap persentasi batang sebesar $24,16 \%$, sedangkan sisanya $(100 \%-24,16 \%$ $=75,84 \%$ ) dipengaruhi oleh variabel lain. Artinya pengaruh terhadap persentasi batang kecil sekali.

Hasil menunjukkan bahwa dosis bokashi terbaik sebesar 40 ton/Ha terhadap persentasi batang rumput gajah. Fase pertumbuhan vegetatif dipengaruhi oleh beberapa faktor diantaranya air, cahaya, dan unsur hara. Jika ketersediaan salah satu dari beberapa faktor tersebut tidak dapat memenuhi kebutuhan tanaman maka akan mengakibatkan terhambatnya pertumbuhan yang kemudian 
memengaruhi proporsi daun dan batang. Menurut Gardner et al., (1991), jumlah dan ukuran daun dipengaruhi oleh faktor genotip dan lingkungan, antara lain unsur hara atau bahan organik.

Proporsi daun dan batang pada penelitian yang didapatkan dengan jumlah terbilang normal, hal ini disebabkan karena adanya penambahan bokashi sehingga pertumbuhan daun dan batang normal. Dalam pemanfaatannya bokashi dapat meningkatkan konsentrasi hara dalam tanah. Bokashi juga dapat memperbaiki tata udara dan air tanah. Dengan demikian, perakaran tanaman akan berkembang dengan baik dan akar dapat menyerap unsur hara yang lebih banyak, terutama unsur hara $\mathrm{N}$ yang akan meningkatkan pembentukan klorofil, sehingga aktivitas fotosintesis lebih meningkat dan dapat meningkatkan jumlah dan luas daun.

\section{Pengaruh Dosis Bokashi terhadap Produksi Berat Segar pada Pemotongan Pertama Rumput Gajah Mini (Pennisetum Purpureum cv. Mott)}

Data hasil pengaruh dosis bokashi terhadap produksi berat segar pada pemotongan pertama rumput gajah mini disajikan dalam Tabel 4.

Tabel 4. Pengaruh perlakuan terhadap produksi berat segar rumput gajah mini

\begin{tabular}{|c|c|c|c|c|}
\hline \multirow{3}{*}{ Perlakuan } & \multicolumn{3}{|c|}{ Ulangan } & \multirow{2}{*}{ Rata-rata } \\
\hline & 1 & 2 & 3 & \\
\hline & $\begin{array}{l}------- \\
---\end{array}$ & ---- & $\mathrm{on} / \mathrm{ha}$ & \\
\hline P0 & 20,75 & 15,20 & 26,05 & $20,67 \pm 5.43$ \\
\hline $\mathrm{P} 1$ & 25,75 & 8,85 & 24,10 & $19,57 \pm 9.32$ \\
\hline $\mathrm{P} 2$ & 43,25 & 43,30 & 42,30 & $42,95 \pm 0.56$ \\
\hline P3 & 21,85 & 28,50 & 51,50 & $33,95 \pm 15.56$ \\
\hline
\end{tabular}

Keterangan : P0 = kontrol (tanpa bokashi) $\mathrm{P} 1=$ dipupuk dengan dosis 30 ton $/ \mathrm{Ha}=$

3000 gram bokashi / petak percobaan

$\mathrm{P} 2=$ dipupuk dengan dosis 40 ton $/ \mathrm{Ha}=$

4000 gram bokashi / petak percobaan

$\mathrm{P} 3=$ dipupuk dengan dosis 50 ton $/ \mathrm{Ha}=$

5000 gram bokashi / petak percobaan

Berdasarkan hasil analisis ragam menunjukkan bahwa perlakuan dosis bokashi berpengaruh nyata $(\mathrm{P}<0,05)$ terhadap produksi berat segar rumput gajah mini yakni perbedaan dosis bokashi di setiap petaknya yang mengakibatkan dosis $\mathrm{C} / \mathrm{N}$ semakin banyak.

Berdasarkan hasil uji lanjut polinomial ortogonal disajikan pada Gambar 4. diperoleh persamaan $\mathrm{Y}=-10,62+38,00 \mathrm{x}-6,71 \mathrm{x}^{2}[0 ; 50$
ton/Ha] ( $\hat{\mathrm{Y}}$ sebagai variabel terikat dan $\mathrm{x}$ sebagai variabel bebas) pada $(\mathrm{P}>0,05)$.

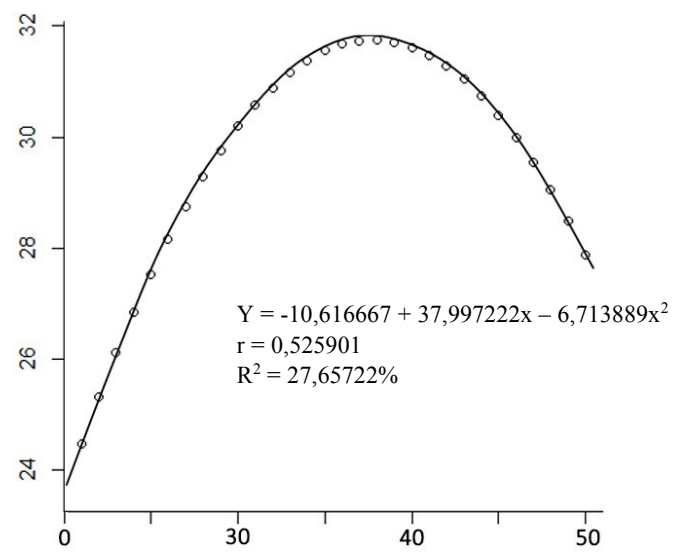

Gambar 4. Grafik produksi berat segar

Berdasarkan persamaan tersebut maka tidak diperoleh titik optimum dosis bokashi karena $\mathrm{P}>0,05$ yang artinya persamaan tersebut tidak valid. Nilai r (koefisien korelasi) diperoleh sebesar 0,53 yang berarti hubungannya sedang. Menurut Sugiyono (2013), jika interval koefisien sebesar 0,40 - 0,599 maka tingkat hubungan dikatakan sedang. Berdasarkan hasil nilai $r$ tingkat hubungannya sedang dan positif antara dosis bokashi terhadap produksi berat segar. menunjukkan bahwa bokashi memiliki tingkat hubungan yang sedang dan positif terhadap produksi berat segar. Nilai $\mathrm{R}^{2}$ (koefisien determinasi) diperoleh sebesar 27,66\% menunjukkan bahwa bokashi berpengaruh terhadap produksi berat segar sebesar $27,66 \%$, sedangkan sisanya $(100 \%-27,66 \%=72,34 \%)$ dipengaruhi oleh variabel lain. Artinya pengaruh terhadap produksi berat segar kecil.

Berdasarkan data tersebut diketahui bahwa dosis bokashi terbaik sebesar 40 ton/Ha terhadap produksi berat segar rumput gajah mini. Hal ini diduga berkaitan dengan peranan $\mathrm{N}$ sebagai komponen yang berperan bagi pertumbuhan tanaman.

Bertambahnya unsur $\mathrm{N}$ dalam tanah berasosiasi dengan pembentukan sel-sel pada tanaman sehingga hal ini meningkatkan proses fotosintesis yang memacu pertumbuhan dan jumlah tanaman sehingga berpengaruh pada berat segar perlakuan. Peranan P sebagai komponen essensisl ADP dan ATP yang bersama-sama berperan penting dalam fotosintesis dan penyerapan ion inilah yang diduga mampu meningkatkan produksi tanaman. Semakin lama umur tanaman akan memberikan 
kesempatan pada tanaman untuk tumbuh lebih lama sehingga jumlah daun yang terbentuk pun lebih banyak dan berpengaruh pada berat segar tanaman. Selanjutnya Sutedjo (2010), menyatakan bahwa pemberian bokashi sebagai sumber bahan organik juga meningkatkan aktivitas mikroorganisme didalam tanah.

Produksi berat segar rumput gajah mini belum maksimal pada pemberian bokashi. Hal ini diduga karena kondisi tanaman kurang akan unsur hara yaitu $\mathrm{C} / \mathrm{N}$ rasio sebesar 4,748 sedangkan standar mutu $\mathrm{C} / \mathrm{N}$ rasio pupuk organik berkisar antara 15-25 (Permentan, 2011). Akibatnya laju fotosintesis dalam memproduksi asimilat tidak meningkat. Pemberian bokashi dapat menambah kandungan humus tanah dan memperbaiki sifat fisik kimia dan biologi tanah. Bokashi berfungsi meningkatkan aktivitas mikroorganisme tanah yang sangat membantu dalam proses perombakan bahan organik, sehingga hara menjadi tersedia dan penyerapan unsur hara yang dibutuhkan oleh tanaman menjadi meningkat dan memungkinkan tanaman mengalami pertumbuhan dan perkembangan vegetatif yang lebih baik.

Pemberian dosis bokashi yang lebih banyak akan mengalami penurunan pada produksi berat segar rumput gajah mini, yang diduga unsur hara yang dibutuhkan tanaman berada dalam keadaan cukup tersedia tetapi berimbang di dalam tanah.

\section{Pengaruh Dosis Bokashi terhadap Produksi Bahan Kering pada Pemotongan Pertama Rumput Gajah Mini (Pennisetum Purpureum cv. Mott)}

Data hasil pengaruh dosis bokashi terhadap produksi bahan kering pada pemotongan pertama rumput gajah mini disajikan dalam Tabel 5.

Tabel 5. Pengaruh perlakuan terhadap produksi bahan kering rumput gajah mini

\begin{tabular}{|c|c|c|c|c|}
\hline \multirow{4}{*}{ Perlakuan } & \multicolumn{3}{|c|}{ Ulangan } & \multirow{2}{*}{ Rata-rata } \\
\hline & 1 & 2 & 3 & \\
\hline & \multicolumn{4}{|c|}{ 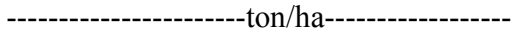 } \\
\hline & \multicolumn{4}{|l|}{---- } \\
\hline P0 & 1,74 & 0,97 & 1,83 & $1,51 \pm 0,47$ \\
\hline $\mathrm{P} 1$ & 2,34 & 0,38 & 1,85 & $1,52 \pm 1,02$ \\
\hline $\mathrm{P} 2$ & 3,65 & 3,65 & 3,59 & $3,63 \pm 0,03$ \\
\hline $\mathrm{P} 3$ & 2,39 & 1,90 & 4,29 & $2,86 \pm 1,26$ \\
\hline
\end{tabular}

$\mathrm{P} 2=$ dipupuk dengan dosis 40 ton $/ \mathrm{Ha}=$ 4000 gram bokashi / petak percobaan

$\mathrm{P} 3=$ dipupuk dengan dosis 50 ton $/ \mathrm{Ha}=$ 5000 gram bokashi / petak percobaan

Berdasarkan hasil analisis ragam menunjukkan bahwa terdapat perlakuan dosis bokashi berpengaruh nyata $(\mathrm{P}<0,05)$ terhadap produksi bahan rumput gajah mini. Rata-rata produksi bahan kering rumput gajah mini pada setiap perlakuan (Tabel 5) yakni kontrol (P0) sebesar 1,51 $\pm 0,47$ ton/ha, dosis bokashi 30 ton/ha (P1) sebesar 1,52 $\pm 1,02$ ton/ha, dosis bokashi 40 ton/ha (P2) sebesar $3,63 \pm 0,03$ ton/ha, dan dosis

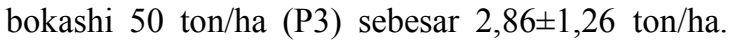
Dapat dilihat bahwa produksi bahan kering tertinggi rumput gajah mini terdapat pada perlakuan P2.

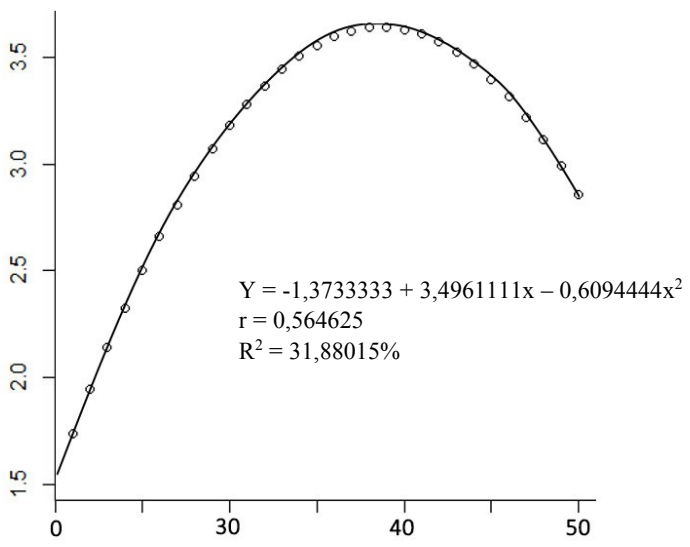

Gambar 5. Grafik produksi bahan kering

Berdasarkan hasil uji lanjut polinomial ortogonal disajikan pada Gambar 5. diperoleh persamaan $\hat{Y}=-1,37+3,50 x-0,61 x^{2}[0 ; 50$ ton/Ha $]$ ( $\hat{Y}$ sebagai variabel terikat dan $\mathrm{x}$ sebagai variabel bebas) pada $(\mathrm{P}<0,01)$. Berdasarkan persamaan tersebut maka tidak diperoleh titik optimum dosis bokashi karena $\mathrm{P}>0,05$ yang artinya persamaan tersebut tidak valid. Nilai $\mathrm{r}$ (koefisien korelasi) diperoleh sebesar 0,56 yang berarti hubungannya sedang. Menurut Sugiyono (2013), jika interval koefisien sebesar 0,40 - 0,599 maka tingkat hubungan dikatakan sedang. Berdasarkan hasil nilai $\mathrm{r}$ tingkat hubungannya sedang dan positif antara dosis bokashi terhadap produksi bahan kering. Nilai $\mathrm{R}^{2}$ (koefisien determinasi) sebesar 31,88\% menunjukkan bahwa bokashi berpengaruh terhadap produksi bahan kering sebesar $31,88 \%$, sedangkan sisanya $(100 \%-31,88 \%=68,12 \%)$ dipengaruhi 
oleh variabel lain. Artinya pengaruh terhadap produksi bahan kering kecil.

Produksi bahan kering terbaik pada dosis bokashi 40 ton/Ha. Hal ini karena produksi bahan kering dipengaruhi oleh produksi berat segar rumput gajah mini. Hal ini juga dipengaruhi oleh banyaknya jumlah daun ataupun anakan sehingga kemampuan fotosintesisnya lebih besar jika dibandingkan dengan jumlah dosis yang lain. Hal ini sesuai dengan pendapat Djunaedy (2009) bahwa produksi tanaman biasanya dipengaruhi oleh pertumbuhan vegetatifnya. Jika pertumbuhan vegetatifnya baik, maka ada kemungkinan produksinya akan baik pula.

Produksi segar dan produksi bahan kering sejalan dengan partumbuhan vegetatif. Reksohadiprodjo (1985) menyatakan bahwa semakin baik partumbuhan vegetatif suatu tanaman maka produksi segar dan produksi bahan kering tanaman tersebut juga akan meningkat. Pertumbuhan vegetatif yang sama akan menghasilkan produksi dan kandungan gizi yang sama pula, semakin baik pertumbuhan vegetatif maka akan menghasilkan produksi dan kandungan gizi tanaman yang semakin tinggi. Arinong (2005) bahwa untuk meningkatkan pertumbuhan dan produksi tanaman, bila bokashi diaplikasikan ke tanah maka akan berfungsi sebagai media atau pakan untuk perkembangan mikroorganisme, sekaligus menambah unsur hara dalam tanah.

\section{SIMPULAN}

Berdasarkan penelitian yang dilakukan dapat diambil kesimpulan sebagai berikut:

1. Penambahan dosis bokashi berpengaruh nyata terhadap tinggi tanaman, produksi berat segar, dan produksi bahan kering, namun tidak berpengaruh nyata terhadap jumlah anakan dan proporsi daun pada pemotongan pertama rumput gajah mini;

2. Pengaruh pupuk bokashi terhadap tinggi tanaman diperoleh penggunaan dosis bokashi optimum sebesar 36,73ton/Ha dan menghasilkan persamaan sebagai berikut $\hat{Y}=$ $60,13+35,38 \mathrm{x}-6.62 \mathrm{x}^{2}[0 ; 50$ ton/Ha $]$ pada $(\mathrm{P}<0,01)$.

Pada jumlah anakan, persentasi batang, produksi berat segar, dan produksi bahan kering tidak diperoleh dosis optimum, sehingga tidak diperoleh juga persamaannya.

\section{DAFTAR PUSTAKA}

Arinong. 2005. Aplikasi berbagai pupuk organik pada tanaman kedelai di lahan kering. Jurnal Sains dan Teknologi. 5 (2):65-72

Djunaedy, A. 2009. Pengaruh jenis dan dosis pupuk bokashi terhadap pertumbuhan dan hasil kacang panjang (Vigna sinensis L.). Agrovigor, 2(1): 42-46.

Gardner, B.R., B.L. Blad, R.E. Maurer, and D.G. Watt. 1991. Relationship between crop temperature and physiological and fenological development of differentially irrigated corn. Agron. J. Vol. 73

Lasamadi, R. D. 2013. Pertumbuhan dan perkembangan Pennisetum Purpureum cv. Mott yang diberi pupuk organik hasil fermentasi EM4. Jurnal Zootek 32 (5): 158171.

Noor, A. dan R.D. Ningsih. 2001. Upaya meningkatkan kesuburan dan produktivitas tanah di lahan kering. Dalam. Prosiding Lokakarya Strategi Pembangunan Pertanian Wilayah Kalimantan. Instalasi Penelitian dan Pengkajian Teknologi Pertanian. Banjarbaru.

Peraturan Menteri Pertanian Republik Indonesia Nomor $\quad 70 /$ Permentan/SR.140/10/2011 Tentang pupuk organik, pupuk hayati dan pembenah tanah

Reksohadiprodjo, S. 1985. Produksi tanaman Hijauan makanan ternak tropik.Cetakan I. Penerbit Fakultas Ekonomi Universitas Gadjah Mada, Yogyakarta.

Sadjadi, B. Herlina, dan W. Supendi. 2017. Level penambahan bokashi kotoran sapi terhadap pertumbuhan dan produksi pada panen pertama rumput raja (Pennisetum purpureophoides). Jurnal Sain Peternakan Indonesia Vol. 12 No. 4

Sholeh, D., Nursyamsi, dan S. J. Adiningsih. 1997. Pengolahan bahan organik dan Nitrogen untuk tanaman padi dan ketela pohon pada lahan kering yang mempunyai tanah ultisol di Lampung. Prosiding: Pertemuan pembahasan dan komunikasi hasil penelitian tanah dan agroklimat, Bidang Kimia dan biologi tanah, Depertemen Pertanian. Pp: 193-206.

Sugiyono. 2013. Metode penelitian kuantitatif, kualitatif dan R\&D. Alfabeta CV. Bandung.

Sutedjo, M. M. 2010. Pupuk dan cara pemupukan. Rineka Cipta, Jakarta. 
Tola, F. H. dan K. Dahlan. 2007. Pengaruh penggunaan dosis pupuk bokashi kotoran sapi terhadap pertumbuhan dan produksi tanaman jagung. Jurnal Agrisistem, 1(3): 3043. 